Dhaka Univ. J. Biol. Sci. 27(1): 1-7, 2018 (January)

\title{
NUMBER OF BYSTANDER, TIME PRESSURE AND GENDER EFFECTS ON ALTRUISTIC BEHAVIOR
}

\author{
Shafrina SAmia* AND Mahfuza Khanam \\ Department of Psychology, University of Dhaka, Dhaka-1000. Bangladesh \\ Key words: Altruistic behaviour, Bystander, Time pressure, Gender
}

\begin{abstract}
The effects of number of bystander, time pressure and gender on showing altruistic behavior was investigated. This covered three hypotheses that: (i) individual would exhibit more altruistic behavior to the victim when they are alone in a situation than being in a group, (ii) time pressure would inhibit altruistic behavior and (iii) there would be no differences between males and females in case of showing altruistic behavior. A total of 40 individuals (20 males and 20 females) and another 20 groups of strangers were the sample of this study and three field experiments were done to examine the hypotheses. Findings revealed that increasing number of bystanders decreased the probability of showing altruistic behavior, under time pressure people less likely to help others and no significant difference was found between males and females in showing altruistic behaviour. The result of the present study can provide a greater understanding of why people fail to do what is morally expected and thus lead to a greater tolerance and understanding of others.
\end{abstract}

\section{Introduction}

Altruism refers to any behavior that is designed to increase another person's welfare, and particularly those actions that do not seem to provide a direct reward to the person who performs them. It occurs when we donate blood, stop to help a stranger who has been stranded on the highway, when we volunteer at a homeless shelter or donate to a charity, or when we get involved to prevent a crime from occurring.

When things go wrong, like hijacking, robbery or murder of a person in front of a crowd it is usually the bystander who is being blamed for failing to act morally. We attribute these failures, to expressions of bad character traits. But there have some factors which contribute to decision of helping others. Some of these factors may be situational, like they may not notice the incident which demands help because they were in a hurry or they believe the victim is responsible for their current state. On the other hand if many bystanders present in the situation then a person may become confused whether to take

\footnotetext{
*Author for correspondence: <safrina.samia@yahoo.com>
} 
initiative to help the victim or not. Mood of a person and their personality traits also have an important effect on altruistic behavior. In addition to these situational and individualistic factors, there are some categorical characteristics that can impact the altruistic behavior like religion and sex differences particularly when youths move into adolescence. A lot of these factors coincide with each other and more than one can be present while deciding whether an individual helps another.

The present research investigate the effects of some of these variables on altruistic behavior.

The bystander effect or bystander apathy is a social psychological phenomenon that refers to cases in which individuals do not offer any means of help to a victim when other people are present. As the number of bystanders increases, any given bystander is less likely to notice the incident, less likely to interpret the incident as a problem or an emergency, and less likely to assume responsibility for taking action ${ }^{(1)}$. Priming a social context is one of the reason for inhibit helping behaviour. Imagining being around one other person or being around a group of people affect a person's willingness to help (2). Group cohesiveness is another variable that can affect the helping behavior of a bystander. The more cohesive a group, the more likely the group will act in accordance to the social responsibility norm ${ }^{(3)}$. Increasing group size inhibited intervention in a street violence scenario when bystanders were strangers but encouraged intervention when bystanders were friends ${ }^{(4)}$.

Conditions of time and the pressures the participants were faced with had a significant effect on helping. The more time people had, the more likely they were to help ${ }^{(5)}$. Those leisurely on their way to an unimportant appointment usually stopped to help ${ }^{(6)}$.

When investigators tried to find out the role of gender, they found controversial results. In showing altruistic behavior male and female have no differences (7). Although sometimes we see male are more helpful than female in some specific situation. Men offer more help when intervention is dangerous (consistent with the heroic role), an audience is present (amplifying normative pressures - men should help people in need), and other helpers are available (amplifying competition to perform) and women, on the other hand, provide their friends with personal favors, emotional support and informal counseling about personal problems more often than men $\mathrm{do}^{(8)}$.

The objectives of the present research were to find out whether individual or group of people exhibit more altruistic behavior, whether time pressure inhibit altruistic behavior and whether gender has any effect on altruistic behavior. Three hypothesis were formed in the present study. They were: (i) individuals would exhibit more altruistic behavior to the victim when they are alone in the situation than being around a group of people, (ii) time pressure would inhibit altruistic behavior and (iii) there would be no difference between males and females in case of their altruistic behavior. 


\section{Materials and Methods}

For the present study 40 individuals (20 male and 20 female) were taken by incidental and purposive sampling method. Beside this 40 participants, another 20 groups of strangers consisted of at least 5 girls or boys were also included in the present study as sample. The age of the participants ranged from 18 to 30 years. Most of them belong to middle to higher class family.

A pile of loose papers and some books were used for conducting the present three experiments.

The experiments were conducted at Dhaka University campus, in every working day near 9 a.m. - 3 p.m. and in between January, 2015 - October, 2015. The first experiment was conducted to see the effect of number of bystanders. For this, the experimenter looked for a person standing alone in a public place, with no other person present within ten meters. The person was not participating in any specific activity to ensure that he/she would notice the event. Then the experimenter acted by dropping a pile of loose pages from a folder and some books close to the person (respondent) 'accidentally'. The respondent was defined as helping if he or she picked up one or more pages or books. In cases where a third person started helping, the trial was not included in the results. This process of acting was repeated for each 20 individuals separately. Among them 10 were females and 10 were males.

The second experiment was conducted to see the effect of group on helping behavior. For this, the same incident was acted in front of a group of people consisted of 5 or more individuals who were busy with talking with each other. The group was defined as helping if any one individual from the group helped the experimenter by picking up the pages or books. For each 20 groups this act was repeated separately.

To measure the effect of time pressure third experiment was conducted. The experimenter was same in all these three experiments. For the third experiment, the experimenter looked for persons who were waiting for the bus in a bus stoppage. Here three bus stoppages (Carzon Hall, TSC, Mall Chattar) of Dhaka University campus were used to conduct the experiment. The experimenter acted the above incident when the bus was seen coming closer to the stoppage. Then the experimenter observed whether any of these people, would help the experimenter to pick up the loose pages or books as he/she was under time pressure to catch the bus. In cases where a third person started helping, the trial was not included in the results. For 20 individuals this procedure was repeated.

\section{Results and Discussion}

To investigate the effects of number of bystanders, time pressure and gender on altruistic behavior, percentage formula and chi-square tests was used. Results have been reported by percentage and chi-square tables as follows. 
Table 1 indicates that 55\% bystanders offered help when he/she was alone in the situation, while $45 \%$ bystanders did not offer any help to the victim. When many bystanders (group of people) were present in the help seeking situation $20 \%$ people came forward to help, while $80 \%$ people ignore the incident.

Table 1. Number and percentages of bystander showing altruistic behaviour.

\begin{tabular}{lcccc}
\hline \multirow{2}{*}{ No. of bystanders } & \multicolumn{2}{c}{ Helping } & \multicolumn{2}{c}{ Not helping } \\
\cline { 2 - 5 } & $\begin{array}{c}\text { Number of } \\
\text { persons }\end{array}$ & $\begin{array}{c}\text { Percentage } \\
\text { of persons }\end{array}$ & $\begin{array}{c}\text { Number of } \\
\text { persons }\end{array}$ & $\begin{array}{c}\text { Percentage } \\
\text { of persons }\end{array}$ \\
\hline Presence of one bystander & 11 & 55 & 09 & 45 \\
Presence of many bystander & 04 & 20 & 16 & 80 \\
\hline
\end{tabular}

Table 2. Chi-square table for bystander effect.

\begin{tabular}{lccc}
\hline & Value & $\mathrm{df}$ & Sig. (2-tailed) \\
\hline $\begin{array}{l}\text { Pearson Chi-square } \\
\chi^{2}\end{array}$ & $7.4^{* *}$ & 1 & 0.006522 \\
${ }^{* *} \mathrm{p}<0.01$ & & & \\
\hline
\end{tabular}

Table 2 indicates significant difference on showing altruistic behavior when individual was alone in the situation and when many bystanders present around him/her. This finding supported our first hypothesis that individuals would exhibit more altruistic behavior to the victim when they are alone in the situation than being around a group of people. The reason behind this result can be explained by previous study on diffusion of responsibility and pluralistic ignorance. According to diffusion of responsibility, as the number of witnesses to an emergency increases, each individual's feelings of personal responsibility for helping the victim decrease because the pressures to intervene are shared among all onlookers and are not unique to anyone. On the other hand, individual who is the only witness to an emergency will be under extreme pressure to offer help. Another reason behind not helping is pluralistic ignorance, which means a state of confusion produces in which everyone is looking to everyone else for an appropriate reaction ${ }^{(9)}$.

Table 3 indicates that in time pressure only 10\% people showed altruistic behavior, but $90 \%$ people did not. On the other hand when people have free time $55 \%$ people helped the victim, while $45 \%$ ignored.

Table 4 indicates significant difference on showing altruistic behavior in time pressure and no time pressure. The result supported our second hypothesis that time pressure 
significantly inhibit altruistic behavior. Time constraints can interfere with the normative demands that usually help people decide when to interfere in an emergency. The greater the time pressure, the less likely the participants were to help a person in distress. It is not the case that people in a hurry consciously decide to deny help. Rather, they are either less likely to realize that a victim is in need of aid, or they experience a conflict between stopping to help the victim and continuing on their way to meet the experimenter ${ }^{(10)}$.

Table 3. Number and percentages of people showing altruistic behavior with and without time pressure.

\begin{tabular}{lcccc}
\hline Time & \multicolumn{2}{c}{ Helping } & \multicolumn{2}{c}{ Not helping } \\
\hline & $\begin{array}{c}\text { Number of } \\
\text { persons }\end{array}$ & $\begin{array}{c}\text { Percentage of } \\
\text { persons }\end{array}$ & $\begin{array}{c}\text { Number of } \\
\text { persons }\end{array}$ & $\begin{array}{c}\text { Percentage of } \\
\text { persons }\end{array}$ \\
\hline Time pressure & 02 & 10 & 18 & 90 \\
\hline No time pressure & 11 & 55 & 09 & 45 \\
\hline
\end{tabular}

Table 4. Chi-square table for time pressure effect.

\begin{tabular}{lccc}
\hline & Value & df & Sig. (2-tailed) \\
\hline $\begin{array}{l}\text { Pearson Chi-square } \\
\chi^{2}\end{array}$ & $13.00^{* * *}$ & 1 & 0.000311 \\
$* * * \mathrm{p}<0.001$. & & & \\
\hline
\end{tabular}

Table 5. Number and percentages of male and female showing altruistic behavior.

\begin{tabular}{|c|c|c|c|c|}
\hline \multirow[t]{2}{*}{ Gender } & \multicolumn{2}{|c|}{ Helping } & \multicolumn{2}{|c|}{ Not helping } \\
\hline & $\begin{array}{l}\text { Number of } \\
\text { persons }\end{array}$ & $\begin{array}{l}\text { Percentage of } \\
\text { persons }\end{array}$ & $\begin{array}{c}\text { Number of } \\
\text { persons }\end{array}$ & $\begin{array}{c}\text { Percentage of } \\
\text { persons }\end{array}$ \\
\hline Male & 05 & 50 & 05 & 50 \\
\hline Female & 06 & 60 & 04 & 40 \\
\hline
\end{tabular}

Table 5 indicates that $50 \%$ male showed altruistic behavior, while $50 \%$ did not. On the other hand $60 \%$ female showed altruistic behavior.

Table 6 indicates that there is no significant difference between male and female in case of showing altruistic behavior. The result supported the third hypothesis. Like other social behaviors, helping can be viewed as role behavior and therefore is being regulated by the social norms that apply to individuals based on the roles they occupy. For this reason, the helping behavior most often exhibited by females differs in type from the 
helping behavior males most often engage in. Specifically, the male role favors helping behavior that is more heroic and chivalrous, while the female role fosters helping that is nurturing and caring. Society as a whole expects and rewards such behavior from each sex. Furthermore, people are more likely to perform a helping behavior that they feel competent and comfortable engaging in ${ }^{(11)}$. As the nature of the present work was a natural one, both male and female showed similar type of helping behavior. Maybe for this reason, no difference in helping behavior has been found.

Table 6. Chi-square table for gender effect.

\begin{tabular}{lccc}
\hline & Value & df & Sig. (2-tailed) \\
\hline $\begin{array}{l}\text { Pearson chi-square } \\
\chi^{2}\end{array}$ & 0.20 & 1 & 0.654 \\
\hline
\end{tabular}

In conclusion, findings of this research can provide a greater understanding of why people fail to do what is morally expected and thus lead to a greater tolerance and understanding of others. If people understand the situational forces that can make them hesitate to intervene, they may better overcome it. On the other hand psychologist and other concern authority can take proper steps for increasing altruistic behavior among people.

\section{References}

1. Darley J M 2000. Bystander Phenomena. Encyclopedia of Psychology 1: 493-95.

2. Garcia SM, K Weaver, JM Darley, and GB Moskowitz 2002. Crowded minds: The implicit bystander effect. Journal of Personality and Social Psychology 83(4): 843.

3. Rutkowski GK, CL Gruder and D Romer 1983. Group cohesiveness, social norms, and bystander intervention. Journal of Personality and Social Psychology 44(3): 545.

4. Levine M and S Crowther 2008. The responsive bystander: How social group membership and group size can encourage as well as inhibit bystander intervention. Journal of Personality and Social Psychology 95(6): 1429.

5. Darley JM and CD Batson 1973. "From Jerusalem to Jericho": A study of situational and dispositional variables in helping behavior. Journal of Personality and Social Psychology 27(1): 100-108.

6. Batson CD, PJ Cochran, MF Biederman, JL Blosser, MJ Ryan and B Vogt 1978. Failure to help when in a hurry: Callousness or conflict? Personality and Social Psychology Bulletin 4(1): 97-101.

7. Goldman M and J Fordyce 1983. Prosocial behavior as affected by eye contact, touch and voice expression. The Journal of Social Psychology 121(1): 125-129.

8. Eagly AH and M Crowley 1986. Gender and helping behavior: A meta-analytic review of the social psychological literature. Psychological Bulletin 100(3): 283 
9. Darley JM and B Latane 1968. Bystander intervention in emergencies: Diffusion of responsibility. Journal of Personality and Social Psychology 8(4): 377.

10. Darley JM and CD Batson 1973. "From Jerusalem to Jericho": A study of situational and dispositional variables in helping behavior. Journal of personality and social psychology 27(1): 100.

11. Belansky ES and AK Boggiano 1994. Predicting Helping Behaviors: The Role of Gender and Instrumental/Expressive Self-Schemata. Sex Roles 30(9): 647.

(Manuscript received on 23 April, 2017; revised on 17 October, 2017) 